\title{
PENGARUH PERCEIVED QUALITY WEBSITE TERHADAP MINAT BERKUNJUNG KE TAMAN WISATA MATAHARI
}

\author{
Apriyanto', Ester Dwi Wahyuni $^{2}$ \\ ${ }^{12}$ Fakultas Ilmu Komunikasi, Universitas Sahid \\ Jl. Soepomo No 84, Jakarta Selatan \\ Email Korespondensi: apriyanto@gmail.com
}

\begin{abstract}
ABSTRAK
Tujuan penelitian ini adalah untuk mengetahui pengaruh perceived quality webside terhadap minat berkunjung ke Taman wisata Matahari. Penilaian atas perceived quality website menggunakan dimensi Technology Acceptance Model (TAM) dengan lima konstruk yaitu perceived Ease of Use, perceived usefulness, attitude toward using, behavioral intention to use, dan actual technology usage. Populasi dalam penelitian ini adalah pengguna website dan pengunjung dewasa Taman Wisata Matahari berjumlah 785.607, pengambilan sampel sebesar 100 dengan menggunanakan rumus Slovin. Penelitian ini menggunakan metode analisis deskriptif, teknik pengumpulan data yang digunakan yaitu kuesioner, sedangkan teknik analisis data yang digunakan yaitu uji validitas dan reliabilitas, uji regresi linear sederhana, uji hipotesis dan analisis korelasi determinasi. Total rata-rata tanggapan pengunjung terhadap perceived quality website Taman Wisata Matahari sebesar 3,99 yang artinya pengunjung setuju. Rata-rata penilaian responden pada minat berkunjung ke Taman Wisata Matahari sebesar 4,13, artinya bahwa website Taman Wisata Matahari sangat mampu mendorong minat pengunjung untuk melakukan kunjungan ke Taman Wisata Matahari. Secara keseluruhan pengaruh perceived quality website terhadap minat berkunjung adalah sebesar $34,4 \%$ dan sisanya sebesar $65,6 \%$ dipengaruhi oleh faktor lain yang tidak temasuk dalam penelitian ini.
\end{abstract}

Kata kunci : perceived quality website, TAM, minat berkunjung

\begin{abstract}
The purpose of this study was to determine the effect of perceived quality webside on interest in visiting Matahari tourism Park. The assessment of the website's perceived quality uses the Dimension of the Technology Acceptance Model (TAM) with five constructs, namely perceived Ease of Use, perceived usefulness, attitude toward using, behavioral intention to use, and actual technology usage. The population in this study were website users and adult visitors to Taman Wisata Matahari amounting to 785.607, the sampling was 100 by using the Slovin formula. This research uses descriptive analysis method, the data collection technique used is a questionnaire, while the data analysis techniques used are validity and reliability tests, simple linear regression test, hypothesis testing and correlation analysis of determination. The total average visitor response to the perceived quality of the Taman Wisata Matahari website is 3.99, which means that visitors agree. The average respondent's assessment of the interest in visiting Matahari Tourism Park is 4.13, which means that the Taman Wisata Matahari website is very capable of encouraging visitors to visit Matahari Tourism Park. Overall, the effect of perceived website quality on visiting interest is $34.4 \%$ and the remaining $65.6 \%$ is influenced by other factors which are not included in this study.
\end{abstract}

Keywords: perceived quality website, TAM, interest in visiting 


\section{PENDAHULUAN}

Bangsa Indonesia tidak hanya dikaruniai tanah air yang memiliki keindahan alam yang melimpah, tetapi juga mempunyai daya tarik yang sangat mengagumkan. Potensi tersebut dapat dimanfaatkan dan dikelola baik dalam sektor perkebunan, pertanian, industri, maupun pariwisata sebagai faktor penunjang ekonomi negara. Salah satunya yang potensial adalah sektor pariwisata dengan memanfaatkan keindahan alam serta keragaman budaya agar dapat menarik perhatian wisatawan baik lokal maupun mancanegera untuk berkunjung ke Indonesia sehingga dapat menghasilkkan devisa bagi negara.

Berdasarkan data dari Kementerian Kebudayaan dan Pariwisata sebagai komoditas ekspor penyumbang devisa bagi perekonomian negara. Kondisi ini dapat dilihat dari nilai devisa yang cenderung meningkat dari tahun 2011-2015. Sektor pariwisata sebagai penyumbang devisa sebagai komoditas ekspor bagi Indonesia dapat dilihat pada Tabel 1.

Tabel 1. Ranking Devisa Pariwisata Terhadap Komoditas Ekspor Lainnya Tahun 2011-2015

\begin{tabular}{|c|c|c|c|c|c|c|}
\hline \multirow{2}{*}{ No. } & \multirow{2}{*}{ Jenis Komoditas } & \multicolumn{5}{|c|}{ Nilai (juta USD) } \\
\hline & & 2011 & 2012 & 2013 & 2014 & 2015 \\
\hline 1 & Minyak \& Gas bumi & $41,477.10$ & 36.977 .00 & $32,633.20$ & $30,318.80$ & $18,552.80$ \\
\hline 2 & Batu bara & $27,221.80$ & $26,166.30$ & $24,501.40$ & $20,819.30$ & $15,943.00$ \\
\hline 3 & Minyak kelapa sawit & $17,261.30$ & $18,845.00$ & $15,839.10$ & $17,464.90$ & $15,385.20$ \\
\hline 4 & Karet Olahan & $14,258.20$ & $10,394.50$ & $9,316.60$ & $7,021.70$ & $5,842.00$ \\
\hline 5 & Pariwisata & $8,554.39$ & $9,120.85$ & $10,054.15$ & $11,166.13$ & $12,225.89$ \\
\hline 6 & Pakaian jadi & $7,801.50$ & $7,304.70$ & $7,501.00$ & $7,450.90$ & $7,271.90$ \\
\hline 7 & Alat listrik & $7,364.30$ & $6,481.90$ & $6,418.60$ & $6,259.10$ & $5,644.80$ \\
\hline 8 & Tekstil & $5,563.30$ & $5,278.10$ & $5,293.60$ & $5,379.70$ & $4,996.00$ \\
\hline 9 & Makanan olahan & $4,802.10$ & $5,135.60$ & $5,434.80$ & $6,486.80$ & $6,456.30$ \\
\hline 10 & Bahan kimia & $4,630.00$ & $3,636.30$ & $3,501.60$ & $3,853.70$ & $2,807.60$ \\
\hline 11 & $\begin{array}{l}\text { Kertas \& barang dr } \\
\text { kertas }\end{array}$ & $4,214.40$ & $3,972.00$ & $3,802.20$ & $3,780.00$ & $3,605.50$ \\
\hline 12 & Kayu olahan & $3,288.90$ & $3,337.70$ & $3,514.50$ & $3,914.10$ & $3,815.80$ \\
\hline
\end{tabular}

Sumber : $\underline{\text { http://www.kemenpar.go.id/asp/ringkasan.asp?c=117 }}$

Pariwisata sebagai sumber devisa juga dapat membuka peluang kesempatan kerja baru untuk masyarakat sekitar tempat wisata dan mengurangi angka pengangguran. Semenjak diberlakukannya UU No. 32 Tahun 2004 mengenai otonomi daerah, masingmasing daerah berusaha mengembangkan potensi yang ada di daerahnya untuk meningkatkan Pendapatan Asli Daerah (PAD), salah satu sektor potensial untuk dikembangkan adalah sektor pariwisata, devisa yang dihasilkan dari sektor pariwisata dialokasikan untuk daerah otonomi tersebut (Nirwandar, 2015).

Kabupaten Bogor merupakan salah satu wilayah di Indonesia yang memiliki banyak potensi tempat wisata yang dapat dikunjungi oleh wisatawan baik mancanegara maupun nusantara, selain itu letaknya yang bersebelahan dengan Ibukota Jakarta sehingga memudahkan akses bagi wisatawan untuk mengunjungi berbagai tempat wisata yang ada di Bogor. Kawasan wisata di Kabupaten Bogor umumnya berbasis wisata alam yang berpotensi untuk dikembangkan lebih lanjut sehingga dapat meningkatan pendapatan daerah. Salah satu daerah di Kabupaten Bogor adalah kawasan Puncak yang dikenal sebagai tempat yang dingin dan segar dan penuh dengan wilayah pegunungan yang alami sehingga menjadi salah satu tujuan wisata di Jawa Barat. Salah satu daerah 
kawasan Puncak yang menjadi tujuan wisata adalah Taman Wisata Matahari (TWM) yang berlokasi di Jalan Raya Puncak Bogor. TWM memiliki luas sekitar 42 hektar.

Taman Wisata Matahari selalu mempromosikan kegiatan-kegiatan yang akan mereka selenggarakan melalui billboard, brosur, spanduk, website, social media (Facebook, Twitter dan Instagram), dan banner yang di pasang di lingkungan Taman Wisata Matahari, serta melakukan pemasaran langsung yaitu dari orang ke orang. Salah satu media promosi yang dianggap efektif adalah website karena seluruh informasi mengenai TamanWisata Matahari dalam website cukup lengkap dan dapat memenuhi jawaban yang diinginkan oleh calon pengunjung. Website resmi Taman Wisata Matahari dapat ditemukan di dalam website http://www.tamanwisatamatahari.co.id.

Setelah sekian bulan berjalan di jalur http, mulai Senin dini hari (30 Mei 2016) telah bermigrasi protokol ke jalur aman https menggunakan SSL dari Comodo. Sehingga nama website menjadi https://tamanwisatamatahari.id. Perpindahan protokol website tamanmisatamatahari.id ini tentu saja bukan tanpa alasan, namun salah satu alasan utama adalah demi keamanan dan kenyamanan setiap pengunjung website Taman Wisata Matahari [dot] id ini.

SSL atau singkatan dari Secure Socket Layer adalah teknologi keamanan standar untuk mendirikan sebuah link yang terenkripsi antara server dan klien, biasanya dikenal dengan server website dan browser atau email server dan email klien (umpamanya, Microsoft Outlook). Teknologi keamanan ini memungkinkan informasi yang sensitif seperti nomor kartu kredit, nomor jaminan sosial, dan kredensial login terkirim dengan aman. Biasanya data yang dikirim antara browser dan server web dalam bentuk teks rentan terhadap penyadapan. Jika penyerang dapat mencegat semua data yang dikirim antara browser dan web server, penyerang bisa melihat dan menggunakan informasi tersebut. Adapun manfaat dari SSL adalah:

1. SSL menjaga informasi sensitif selama dalam proses pengiriman melalui internet dengan cara dienkripsi. Sehingga hanya penerima pesan yang dapat memahami dari hasil enkripsi tersebut.SSL memberikan enskripsi data melalui HTTPS yang akan melindungi data pengunjung website, memberikan integrits data sehingga kalian mengetahui bahwa data atau website tidak mampu dimodifikasi atau dirusak.

2. SSL juga menyediakan otentikasi. Dengan SSL dipastikan informasi terkirim ke server tujuan dan bukannya ke mesin lain yang tidak memiliki hak atas informasi tersebut. Hal ini sangatlah penting karena sifat dasar dari internet yaitu pengiriman data dan informasi yang akan melewati beberapa jumlah mesin.

Setiap mesin, memiliki potensi menjadi website palsu atau adanya peniruan untuk mengelabui pengguna anda mengirimkan informasi ke mesin tersebut. Namun dengan menggunakan PKI (Public Key Infrastructure) dan sertifikat SSL dari penyedia SSL terpercaya, hal ini dapat dihindari.

3. Melindungi Pencurian Data Dalam Bentuk Pemalsuan (Phising) Sebuah email phising adalah email yang dikirim oleh seorang kriminal yang mencoba untuk meniru tampilan website. Email tersebut biasanya berisi tautan ke situs mereka atau menggunakan serangan saat ditengah jalan untuk menggunakan nama domain situs korbannya.

4. SSL dapat meningkatkan peringkat website di Google. Google secara resmi mengumumkan pada 6 Agutus 2014 bahwa enskripsi HTTPS hanya tersedia dengan sertifikat SSL. 
Pada penelitian ini peneliti mendapatkan data primer dari pihak pengelola Taman Wisata Matahari berupa data jumlah pengunjung Taman Wisata Matahari dari bulan Januari 2017 sampai dengan Agustus 2017, berikut peneliti sajikan pada tabel berikut ini.

Tabel 2. Jumlah KunjunganWisatawan Nusantara Ke Taman Wisata Matahari Bulan Januari 2017 s/d Agustus 2017)

\begin{tabular}{|c|c|c|}
\hline No. & Bulan & Jumlah Kunjungan \\
\hline 1 & Januari & 116.600 \\
\hline 2 & Februari & 62.030 \\
\hline 3 & Maret & 93.278 \\
\hline 4 & April & 140.409 \\
\hline 5 & Mei & 153.453 \\
\hline 6 & Juni & 70.702 \\
\hline 7 & Juli & 106.387 \\
\hline 8 & Agustus & 42.748 \\
\hline
\end{tabular}

Sumber : Data Pengelola TWM 2017

Berdasarkan latar belakang tersebut maka perlu diadakan suatu penelitian tentang "Pengaruh Perceived Quality Website Terhadap Minat Berkunjung ke Taman Wisata Matahari”".

\section{Identifikasi Masalah}

Dari pemaparan latar belakang permasalahan tersebut di atas maka ditemukan masalah yang berkaitan dengan strategi promosi Wisata Taman Matahari melalui website adalah strategi promosi yang diterapkan Taman Wisata Matahari khususnya melalui website masih belum mampu menarik pengunjung website Taman Wisata Matahari untuk berkunjung langsung ke Taman Wisata Matahari.

\section{Perceived Quality}

Menurut Keller (2013) Perceived Quality dapat didefinisikan sebagai sebuah persepsi pelanggan terhadap kualitas keseluruhan atau keunggulan dari suatu produk atau jasa jasa dibandingkan dengan yang lain. Schiffman \& Kanuk (2010) mendefinisikan Perceived Quality terbagi menjadi dua bagian utama, yaitu:

1. Perceived Quality of Product

Merupakan persepsi akan kualitas yang didasarkan pada tanda atau karakteristik fisik dari suatu produk itu sendiri, seperti ukuran, warna, rasa atau aroma. Pada kasus tertentu konsumen akan menggunakan karakteristik fisik untuk menilai kualitas dari suatu produk. Konsumen biasa percaya pada evaluasi dari kualitas dari suatu produk berdasarkan dari diri mereka. Penilaian kualitas dari pelanggan terkadang didasarkan pada karakteristik ekstrinsik dari suatu produk. Contohnya meskipun banyak konsumen mengklaim bahwa mereka membeli merek karena merasakan produk tersebut bernilai superior, mereka justru sering tidak mampu membedakan merek yang mereka pilih tersebut tersebut saat diuji dalam blind testing. Banyak penelitian yang menunjukan bahwa kemasan suatu produk mempengaruhi persepesi kualitas dari suatu produk.

\section{Perceived Quality of Services}


Merupakan persepsi kualitas yang didasarkan pada karakteristik jasa yang ditawarkan/diberikan. Dikatakan bahwa lebih sulit bagi konsumen untuk mengevaluasi kualitas jasa/layanan daripada kualitas produk. Dikatakan demikian, karena karakteristik tertentu dari suatu jasa memiliki nilai khas. Kualitas jasa tidak berwujud (intangible), merupakan suatu variabel, tidak tahan lama (perishable), dan kondisi ketika diproduksi dan dikonsumsi terjadi disaat yang bersamaan.

\section{Website}

Perusahaan harus merancang website dalam mewujudkan atau dalam mengekspresikan tujuan, sejarah, produk, dan visi mereka pada tampilan yang menarik dan juga dapat mendorong kunjungan. Menurut Arief (2011:8) website adalah kumpulan dari halaman web yang sudah dipublikasikan di jaringan internet dan memiliki domain yang dapat diakses semua pengguna internet dengan cara mengetik alamatnya. Sedangkan, menurut Hidayat (2010:6) website adalah keseluruhan halaman-halaman web yang terdapat dalam sebuah domain yang mengandung informasi.

\section{Minat Berkunjung}

Minat menjadi awal keputusan seseorang untuk membeli atau tidak membeli suatu produk setelah mengetahui adanya produk di pasar. Minat digambarkan sebagai suatu situasi dan kondisi sikap yang muncul dalam diri yang dipicu oleh rasa ingin untuk mendapatkan atau memiliki sesuatu.

Menurut Rahayu dan Budiyanto (2009:101) atribut-atribut yang dipertimbang kan seseorang dalam berkunjung, yaitu :

1. Kebijakan Produk

Produk wisata harus sesuai dengan apa yang dicari dan disukai oleh masyarakat atau sesuai dengan permintaan pasar. Karena apa yang dicari dan disukai wisatawan itu tergantung dari motif perjalanan wisata, yang diukur dengan kebersihan tempat wisata, layout tempat wisata, dan citra dari tempat wisata tersebut.

2. Kebijakan Harga

Harga produk pariwisata adalah jumlah harga komponen-komponen kebijakan harga berusaha menentukan harga yang tepat untuk produk kepariwisataan, sehingga seimbang dengan daya beli pasar dan menarik bagi calon wisatawan. Untuk keperluan tersebut orang harus mengenal pasar pariwisata, khususnya mengenai daya belinya. Daya beli tergantung dari kekayaan yang ada didalam masyarakat pasar, yang diukur dengan harga tiket masuk, potongan harga, dan harga penggunaan fasilitas.

3. Tempat/Distribusi

Fungsi distribusi menghadirkan produk di tengah-tengah pasar. Dengan adanya produk ditengah pasar, para masyarakat dapat dengan mudah membelinya, yang diukur dengan akses menuju tempat lokasi wisata, luas lokasi dan kondisi jalan tempat wisata.

4. Bauran Promosi

Sasaran terakhir dari semua pemasaran promosi ialah orang-orang yang akhirnya mengeluarkan uang dan waktunya untuk mengadakan perjalanan wisata. Berhasil atau tidaknya promosi kepariwisataan dapat diukur dari banyaknya informasi yang 
diminta dan besarnya volume kedatangan wisatawan. Promosi dapat berupa promosi langsung dan promosi tidak langsung.

5. Pelayanan dan Fasilitas

Fasilitas sangat berhubungan dengan unsur-unsur yang terdapat dalam jasa. Kaitan pelayanan pada wisatawan dengan semua fasilitas yang kemungkinan mereka melakukan perjalanan wisata, yang diukur dengan lahan parkir, tempat ibadah dan fasilitas yang ada ditempat wisata.

\section{Technology Acceptance Model (TAM)}

Technology Acceptance Model adalah teori sistem informasi yang membuat model tentang proses pengguna mau menerima dan menggunakan teknologi. Model ini menjelaskan ketika pengguna menggunakan sistem informasi, sejumlah faktor mempengaruhi keputusan mereka mengenai bagaimana dan kapan menggunakan sistem informasi tersebut. Konsep Technology Acceptance Model dilandasi teori tindakan alasan (Theory of Reasoned Action - TRA) yang dikembangkan Fishben dan Ajzen (1975). Dalam TAM, penerimaan pemakai sistem informasi ditentukan oleh dua faktor kunci yaitu perceived usefulness dan perceived ease of use.

Technology Acceptance Model (TAM) berteori bahwa niat seseorang untuk menggunakan sistem atau teknologi ditentukan oleh dua faktor, yaitu persepsi penggunaan (perceived usefulness), adalah tingkat kepercayaan individu bahwa penggunaan teknologi akan meningkatkan kinerjanya, dan persepsi kemudahan penggunaan (perceived ease of use), adalah tingkat kepercayaan individu bahwa penggunaan teknologi membuat lebih mudah menyelesaikan pekerjaan.

Penelitian mengenai faktor-faktor yang memprediksi diterimanya teknologi informasi menerima banyak perhatian karena banyak perusahaan mengadopsi dan menggunakan teknologi informasi, dan TAM merupakan salah satu model yang dapat digunakan untuk menyelidiki hal tersebut (Mohd, 2011).

Persepsi penggunaan (perceived usefulness) dan kemudahan penggunaan (Perceived ease of use) keduanya mempunyai pengaruh ke niat perilaku (behavioral intentio to use). Kemudahan penggunaan persepsian (perceived ease of use) mempengaruhi kegunaan persepsian (perceived usefulness).

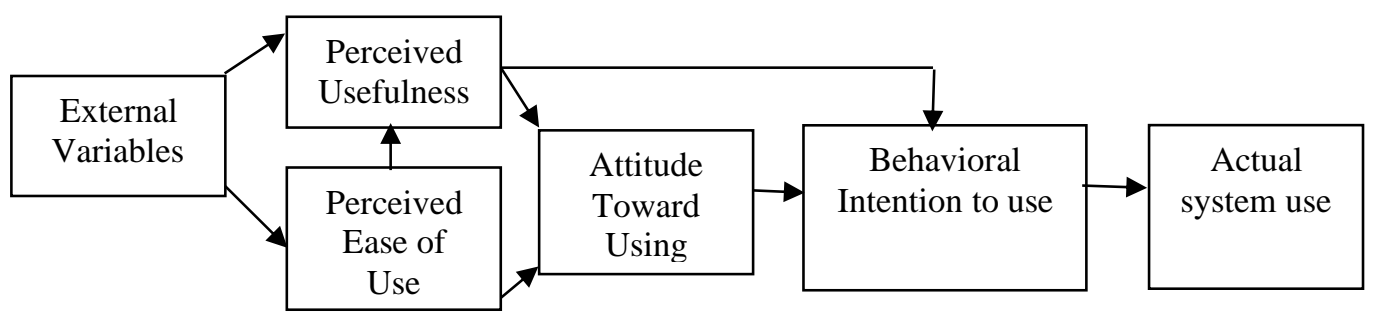

Sumber : Mohd (2011)

Gambar 2.1 Technology Acceptance Model

Dalam Technology Acceptance Model (TAM) dikenal ada lima konstruk seperti terlihat pada gambar diatas, yaitu :

1. Perceived Usefulness (persepsi penggunaan)

Sejauh mana seseorang percaya bahwa menggunakan suatu teknologi akan bebas dari usaha. 
2. Perceived Ease of Use (persepsi kemudahan penggunaan)

Sejauh mana seseorang percaya bahwa suatu teknologi akan meningkatkan kinerjanya.

3. Attitude Toward Using (sikap terhadap penggunaan teknologi)

Sebagai evaluasi dari pemakai tentang ketertarikannya dalam menggunakan teknologi.

4. Behavioral Intention to Use (minat menggunakan teknologi)

Minat atau perilaku seseorang untuk melakukan perilaku tertentu.

5. Actual Technology Usage (penggunaan teknologi sesungguhnya)

Diukur dengan jumlah waktu yang digunakan untuk berinteraksi dengan teknologi dan frekuensi penggunaan teknologi tersebut.

\section{Kerangka Pemikiran}

untuk memudahkan peneliti dalam melaksanakan penelitian mengenai perceived quality website dalam mempromosikan Taman Wisata Matahari maka peneliti membuat kerangka berfikir sebagai panduan serta memberikan batasan terhadap penelitian ini sehingga tujuan penelitian dapat tercapai dengan baik.

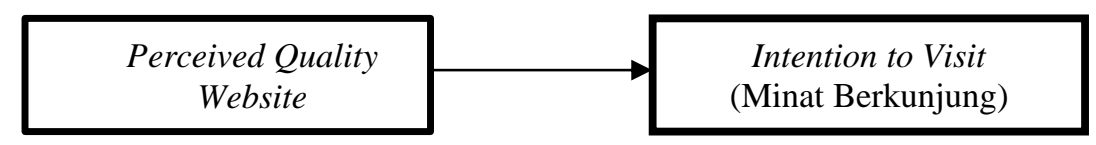

Gambar 2.2 Kerangka Pemikiran

\section{Hipotesis}

Berdasarkan kerangka pemikiran dan tujuan penelitian, maka dihipotesiskan bahwa perceived quality website sebagai media promosi berpengaruh terhadap minat berkunjung di Taman Wisata Matahari

\section{METODE PENELITIAN}

\section{Tempat dan Waktu Penelitian}

Penelitian ini dilakukan di objek wisata Taman Wisata Matahari yang beralamat di J1. Raya Puncak Km 77, Cilember, Cisarua, Kota Bogor, Jawa Barat 16750. Penelitian ini dilakukan pada bulan September 2017 sampai penyelesaian penulisan penelitian yang meliputi observasi lapangan langsung ke Taman Wisata Matahari, melakukan wawancara kepada pihak pengelola Taman Wisata Matahari untuk mendapatkan informasi, pengumpulan data primer dan sekunder dengan studi kepustakaan atau literatur dan dokumen.

\section{Populasi dan Sampel \\ Populasi}

Populasi adalah wilayah generalisasi yang terdiri atas objek atau subjek yang mempunyai kualitas dan karakteristik tertentu yang ditetapkan oleh peneliti untuk dipelajari dan kemudian ditarik kesimpulannya, menurut Sugiyono (2014:80). Satu orang 
pun dapat digunakan sebagai populasi, karena satu orang itu mempunyai berbagai karakteristik, misalnya gaya bicaranya, disiplin pribadi, hobi, cara bergaul, kepemimpinannya dan lain-lain. Oleh sebab itu yang menjadi populasi dalam penelitian ini adalah seluruh pengunjung yang pernah berkunjung ke Taman Wisata Matahari.

Populasi dalam penelitian ini adalah pengguna website dan pengunjung dewasa Taman Wisata Matahari bulan Januari s/d Agustus 2017 berjumlah 785.607 orang

\section{Sampel}

Teknik penarikan sampel dari penelitian ini adalah nonprobability sampling dengan metode accidental sampling. Nonprobability sampling menurut Sugiyono (2014:84) adalah teknik pengambilan sampel yang tidak memberi peluang atau kesempatan sama bagi setiap unsur atau anggota populasi untuk dipilih menjadi sampel. Sampel yang dipilih berdasarkan pertimbangan-pertimbangan tertentu dari peneliti, sedangkan teknik accidental sampling menurut Sugiyono (2014:85) merupakan teknik penentuan sampel berdasarkan kebetulan, yaitu siapa saja yang secara kebetulan atau insidental bertemu dengan peneliti dapat digunakan sebagai sampel, bila dipandang orang yang kebetulan ditemui itu cocok sebagai sumber data.

Untuk mendukung penelitian ini dalam menentukan jumlah sampel, peneliti menggunakan rumus Slovin.

\section{Metode Penelitian}

Metode penelitian yang digunakan peneliti adalah metode kuantitatif. Marzuki (2005:16) mendefinisikan penelitian kuantitatif adalah penelitian yang mempergunakan data angka dengan berbagai klasifikasi dalam bentuk persentase, frekuensi, nilai rata-rata, yang diolah secara matematis dengan rumus-rumus statistik. Metode riset yang digunakan dalam penelitian ini adalah survei dengan menyebarkan kuesioner.

Jenis penelitian yang digunakan adalah penelitian konklusif deskriptif. Dapat dijelaskan menurut Malhotra (2010:106) penelitian deskriptif adalah jenis penelitian yang tujuan utamanya adalah menggambarkan sesuatu, biasanya mengenai karakteristik. Penelitian konklusif merupakan penelitian yang dirancang untuk membantu pengambilan keputusan dalam menentukan, mengevaluasi, dan memilih alternatif terbaik dalam memecahkan masalah.

\subsection{Operasionalisasi Variabel}

Dalam penelitian ini, peneliti menggunakan satu variabel bebas (X) yaitu Perceived Quality yang terdiri dari dimensi TAM, serta satu variabel terikat (Y) yaitu Minat Berkunjung. Untuk lebih jelasnya mengenai operasional variabel dari penelitian ini dapat dilihat pada tabel berikut:

Tabel 3.1 Operasional Variabel

\begin{tabular}{|l|l|l|}
\hline Variabel & \multicolumn{1}{|c|}{ Dimensi } & \multicolumn{1}{c|}{ Indikator } \\
\hline \multirow{7}{*}{$\begin{array}{c}\text { Perceived Ease of Use } \\
\text { (persepsi kemudahan } \\
\text { penggunaan) }\end{array}$} & $\begin{array}{l}\text { Desain halaman muka (homepage) website menarik } \\
\text { dan mudah dimengerti }\end{array}$ & $\begin{array}{l}\text { Kemudahan dalam mencari informasi (promo tiket } \\
\text { masuk, harga spesial tiket masuk rombongan, wahana } \\
\text { permainan dan paket wisata lainnya) }\end{array}$ \\
\cline { 3 - 3 } & $\begin{array}{l}\text { Website mudah diakses dengan komputer maupun } \\
\text { telepon gengam (HP) }\end{array}$ \\
\cline { 3 - 3 } & & Informasi dalam website selalu up to date \\
\hline
\end{tabular}




\begin{tabular}{|c|c|c|}
\hline Variabel & Dimensi & Indikator \\
\hline \multirow{10}{*}{$\begin{array}{l}\text { Perceived } \\
\text { Quality }\end{array}$} & \multirow{2}{*}{$\begin{array}{l}\text { Perceived Usefulness } \\
\text { (persepsi penggunaan) }\end{array}$} & Informasi di dalam website lengkap dan jelas \\
\hline & & Tampilan kualitas visual dalam website menarik \\
\hline & \multirow{3}{*}{$\begin{array}{l}\text { Attitude Toward Using } \\
\quad \text { (sikap terhadap } \\
\text { penggunaan teknologi) }\end{array}$} & $\begin{array}{l}\text { Mengunjungi website Taman Wisata Matahari sangat } \\
\text { bermanfaat bagi saya }\end{array}$ \\
\hline & & $\begin{array}{l}\text { Fitur-fitur dalam website Taman Wisata Matahari } \\
\text { sangat menyenangkan }\end{array}$ \\
\hline & & $\begin{array}{l}\text { Mengunjungi website Taman Wisata Matahari sangat } \\
\text { membosankan }\end{array}$ \\
\hline & \multirow{3}{*}{$\begin{array}{c}\text { Behavioral Intention to } \\
\text { Use (minat } \\
\text { menggunakan } \\
\text { teknologi) }\end{array}$} & Website Taman Wisata Matahari menarik untuk dibuka \\
\hline & & $\begin{array}{l}\text { Mencari informasi dalam website merupakan ide yang } \\
\text { bagus }\end{array}$ \\
\hline & & $\begin{array}{l}\text { Membuka website Taman Wisata Matahari sebelum } \\
\text { berkunjung sangat perlu }\end{array}$ \\
\hline & \multirow{2}{*}{$\begin{array}{l}\text { Actual Technology } \\
\text { Usage (penggunaan } \\
\text { teknologi } \\
\text { sesungguhnya) }\end{array}$} & $\begin{array}{l}\text { Semua informasi dalam website sangat menarik untuk } \\
\text { dibaca }\end{array}$ \\
\hline & & $\begin{array}{l}\text { Fitur-fitur dalam website sangat menarik untuk } \\
\text { dikunjungi }\end{array}$ \\
\hline \multirow{3}{*}{\multicolumn{2}{|c|}{$\begin{array}{l}\text { Intention to Visit } \\
\text { (minat berkunjung) }\end{array}$}} & $\begin{array}{l}\text { Saya terdorong untuk berkunjung langsung karena } \\
\text { informasi yang ada pada website }\end{array}$ \\
\hline & & $\begin{array}{l}\text { Promosi pada website mempengaruhi saya untuk } \\
\text { berkunjung langsung }\end{array}$ \\
\hline & & $\begin{array}{l}\text { Saya akan menyarankan orang lain untuk mengunjungi } \\
\text { website agar mendapatkan informasi sebelum } \\
\text { berkunjung langsung }\end{array}$ \\
\hline
\end{tabular}

\section{Analisis Penelitian}

Dalam penelitian kuantitatif, analisis data dengan menggunakan metode deskriptif yang menguraikan nilai rata-rata yang terdapat dalam permasalahan penelitian. Pada tahap ini data dikumpulkan dan dimanfaatkan untuk menjawab persoalan yang diajukan dalam rumusan masalah yaitu :

1. Data profil pengunjung Taman Wisata Matahari yang dianalisis secara deskriptif dengan menggunakan tabulasi dari kuesioner yang disebarkan kepada responden

2. Data perceived quality website Taman Wisata Matahari dianalisis secara deskriptif dengan menggunakan tabulasi dari kuesioner yang disebarkan kepada responden.

3. Data minat berkunjung di Taman Wisata Matahari dianalisis secara deskriptif dengan menggunakan tabulasi dari kuesioner yang disebarkan kepada responden.

4. Berdasarkan rumusan masalah penelitian, dihipotesiskan bahwa dimensi Perceived Ease of Use (persepsi kemudahan penggunaan), Perceived Usefulness (persepsi penggunaan), Attitude Toward Using (sikap terhadap penggunaan teknologi), Behavioral Intention to Use (minat menggunakan teknologi), Actual Technology Usage (penggunaan teknologi sesungguhnya) berpengaruh terhadap minat berkunjung ke Taman Wisata Matahari.

\section{Uji Validitas dan Reliabilitas}

Pengujian validitas pada penelitian evaluatif ini menggunakan logical validity (validitas logis). Validitas logis untuk sebuah instrumen menunjuk pada kondisi sebuah 
instrumen yang memenuhi syarat valid berdasarkan hasil penalaran dan rasional. Instrumen yang diuji validitasnya adalah intrumen komponen konteks, masukan, proses dan hasil. Uji validitas pada penelitian ini menggunakan teknik uji validitas korelasi product moment yang dikemukakan oleh Pearson dalam Sugiyono (2014:183).

\section{Analisis Regresi Linier Sederhana}

Untuk mengetahui pengaruh Perceived Quality Website terhadap Minat Berkunjung dalam penelitian ini, teknik analisis data yang digunakan adalah analisa regresi linier sederhana. Analisis regresi linear sederhana adalah analisis data yang digunakan untuk mengetahui seberapa jauh pengaruh perubahan nilai variabel dependen bila variabel independen dinaikkan atau diturunkan.

\section{Uji Hipotesis}

Berdasarkan permasalahan dalam penelitian ini, maka peneliti melakukan uji hipotesis dengan uji t dengan derajat signifikansi sebesar 0,05 , hipotesis yang didapat sebagai berikut:

$\mathrm{H} 0=$ perceived quality website sebagai media promosi tidak berpengaruh terhadap minat berkunjung (intention to visit).

$\mathrm{H} 1$ = perceived quality website sebagai media promosi berpengaruh terhadap minat berkunjung (intention to visit).

\section{Koefisien Determinasi}

Analisis koefisien determinasi $\left(\mathrm{R}^{2}\right)$ digunakan untuk mengetahui besarnya pengaruh variabel bebas (independent) terhadap variable terikat (dependent). Besarnya koefisien determinasi berkisar antara angka 0 sampai dengan 1, apabila nilai koefisien determinasi mendekati angka 1, maka semakin besar pengaruh variable independen terhadap variable dependen. Rumus untuk mencari nilai kontribusi variabel bebas terhadap variabel terikat adalah sebagai berikut: $K D=\left(R^{2}\right) \times 100 \%$.

\section{HASIL DAN PEMBAHASAN}

\section{Karakteristik Responden}

Untuk mengetahui perceived quality website sebagai media promosi dalam meningkatkan daya tarik pengunjug, maka dilakukan penyebaran kuesioner dengan menggunakan teknik nonprobability sampling dengan metode purposive sampling dengan menyebarkan 100 kuesioner kepada pengunjung Taman Wisata Matahari yang telah melakukan browsing ke website Taman Wisata Matahari, dan kepada pengunjung dewasa Taman Wisata Matahari. Kuesioner dibuat secara tertulis. 100 kuesioner disebar secara langsung kepada responden. Berikut merupakan tabel-tabel yang menjelaskan tentang identitas responden.

\section{Responden Berdasarkan Jenis Kelamin}


Berdasarkan jenis kelamin, peneliti membagi jenis kelamin respondenmenjadi dua kelompok, yaitu laki-laki danperempuan. Berikut peneliti cantumkan hasil jumlah kuesioner yang telah disebarkan kepada responden berdasarkan jenis kelamin pada tabel berikut ini :

Tabel 4.1 Responden Berdasarkan Jenis Kelamin

\begin{tabular}{|c|c|c|}
\hline Jenis Kelamin & Jumlah & Persentase \\
\hline Laki-laki & 51 & $51 \%$ \\
\hline Perempuan & 48 & $48 \%$ \\
\hline Total & 100 & $100 \%$ \\
\hline \multicolumn{2}{c}{ Sumber : Hasil Olahan Kuesioner (2017) } \\
\hline
\end{tabular}

Berdasarkan Tabel 4.1 diatas dapat diketahui bahwa sebagian besar responden dalam penelitian ini adalah Laki-laki yakni sebanyak 51 responden atau 51\%, sedangkan yang mempunyai jenis kelamin Perempuan jumlahnya sebanyak 48 responden atau $48 \%$. Dengan demikian dapat disimpulkan bahwa jumlah pengunjung Taman Wisata Matahari yang melakukan browsing ke website Taman Wisata Matahari sebagian besar adalah lakilaki yang mendominasi dari jumlah pengunjung perempuan karena peminat wisata arung jeram yang ada di website Taman Wisata Matahari sangat dominan disukai oleh laki-laki.

\section{Responden Berdasarkan Usia}

Berdasarkan usia, peneliti membagi kedalam empat kelompok usia, yaitu lebih dari 20 tahun, lebih dari 30 tahun, lebih dari 40 tahun dan sisanya lebih dari 50 tahun. Berikut peneliti cantumkan hasil jumlah kuesioner berdasarkan umur responden pada tabel berikut :

Tabel 4.2 Responden Berdasarkan Umur

\begin{tabular}{|c|c|c|}
\hline Umur & Jumlah & Persentase \\
\hline 21-30 Tahun & 19 & $19 \%$ \\
\hline $31-40$ Tahun & 36 & $36 \%$ \\
\hline 41-50 Tahun & 31 & $31 \%$ \\
\hline >50 Tahun & 14 & $14 \%$ \\
\hline Total & 100 & $100 \%$ \\
\hline
\end{tabular}

Sumber : Hasil Olahan Kuesioner (2017)

Berdasarkan Tabel 4.2 diatas dapat diketahui bahwa jumlah pengunjung Taman Wisata Matahari yang telah melakukan browsing ke website Taman Wisata Matahari terbanyak yaitu berusia 31 - 40 tahun dengan jumlah 36 orang atau $36 \%$, responden berdasarkan usia 41-50 tahun menempati urutan kedua terbanyak yaitu sebesar 31 orang atau 31\%, responden yang berusia 21-30 tahun menempati urutan ketiga yaitu 19 orang atau $19 \%$, sedang responden yang menempati urutan keempat adalah responden yang berusia diatas 50 tahun yaitu sebanyak 14 orang atau $14 \%$.

\section{Responden Berdasarkan Pekerjaan}

Berdasarkan pekerjaan, peneliti membagi menjadi lima kelompok pekerjaan, yaitu Pegawai Negeri (PNS), Pegawai Swasta, Wirausaha, TNI/POLRI, Lainnya yang tidak mau disebutkan pekerjaan. Berikut peneliti cantumkan hasil jumlah kuesioner berdasarkan pekerjaan responden pada tabel berikut : 
Tabel 4.3 Responden Berdasarkan Pekerjaan

\begin{tabular}{|c|c|c|}
\hline Pekerjaan & Jumlah & Persentase \\
\hline Pegawai Negeri (PNS) & 5 & $5 \%$ \\
\hline Pegawai Swasta & 63 & $63 \%$ \\
\hline Wiraswasta & 8 & $8 \%$ \\
\hline TNI/POLRI & 0 & $0 \%$ \\
\hline Lainnya & 14 & $14 \%$ \\
\hline Total & 100 & $100 \%$ \\
\hline
\end{tabular}

Berdasarkan tabel 4.3 pekerjaan responden sebagian besar adalah pegawai swasta sebesar $63 \%$. Hal ini menunjukan bahwa pengunjung banyak menuju ke Taman Wisata Matahari terlebih dahulu melakukan browsing ke website Taman Wisata Matahari adalah pegawai swasta sebuah perusahaan yang sedang mengadakan kegiatan Family Gathering dan kegiatan perusahaan lainnya.

\section{Responden Berdasarkan Jumlah Kunjungan Ke Website Taman Wisata Matahari}

Berikut peneliti cantumkan hasil jumlah kuesioner berdasarkan frekuensi responden melakukan browsing ke website Taman Wisata Matahari, dapat dijelaskan pada tabel berikut ini :

Tabel 4.4 Responden Berdasarkan Jumlah Frekuensi Browsing ke Website Taman Wisata Matahari

\begin{tabular}{|c|c|c|}
\hline Frekuensi Browsing Website & Orang & Presentase \\
\hline 1 kali & 72 & $72 \%$ \\
\hline $2 \mathrm{kali}$ & 20 & $20 \%$ \\
\hline $3 \mathrm{kali}$ & 7 & $7 \%$ \\
\hline$>3 \mathrm{kali}$ & 0 & $0 \%$ \\
\hline Total & 100 & $100 \%$ \\
\hline
\end{tabular}

Sumber : Hasil Olahan Kuesioner (2017)

Dapat dijelaskan bahwa $72 \%$ responden hanya melakukan 1 kali browsing ke website Taman Wisata Matahari. Berdasarkan penjelasan dari responden, hal ini disebabkan responden yang sebagian besar pegawai swasta menjelaskan bahwa mereka berkunjung untuk berwisata di akhir pekan terlebih dahulu melihat atau browsing ke berbagai website, dan pilihan jatuh pada website Taman Wisata Matahari karena banyak menyajikan wahana rekreasi juga mengusung motto Education Park, yaitu menciptakan wahana-wahana pendidikan yang isinya mengajarkan kepada para tunas bangsa untuk dapat mengenal dan lebih dekat dengan alam, seperti Wahana Agro sawah, Wahana Ternak dan Wahana Pendidikan alam. Semua wahana-wahana tersebut kegiatannya sangat erat dan kental dengan unsur pendidikan, seperti membajak sawah, menanam padi, memelihara tanaman, memelihara hewan ternak, dan bagaimana cara memetik hasil dari bercocok tanam dan berternak, seperti menumbuk padi, menapi dan memerah susu sapi.wisata alam dan petualangan. Jadi mereka tidak pernah mengunjungi Taman Wisata Matahari sebelumnya.

Uji Validitas dan Reliabilitas 
Untuk menguji validitas kuesioner, peneliti menggunakan bantuan aplikasi Statistical Product and Service Solution (SPSS) dengan menggunakan taraf signifikansi two tail sebesar 0,05 dengan nilai $\mathrm{N}$ adalah 100. Berdasarkan tabel $\mathrm{r}$ product moment Pearson, maka $r$ tabel adalah 0,195.

Tabel 4.5. Uji Validitas Variabel X (Perceived Quality)

\begin{tabular}{|c|c|c|c|c|}
\hline No & Pernyataan & $r$ tabel & r hitung & Validitas \\
\hline 1 & $\begin{array}{l}\text { Desain halaman muka (homepage) website menarik dan } \\
\text { mudah dimengerti }\end{array}$ & 0,195 & 0,616 & Valid \\
\hline 2 & $\begin{array}{l}\text { Kemudahan dalam mencari informasi (promo tiket masuk, } \\
\text { harga spesial tiket masuk rombongan, wahana permainan, } \\
\text { dan paket wisata lainnya) }\end{array}$ & 0,195 & 0,528 & Valid \\
\hline 3 & Website mudah diakses dari komputer \& HP & 0,195 & 0,577 & Valid \\
\hline 4 & Informasi dalam website selalu up to date & 0,195 & 0,449 & Valid \\
\hline 5 & Informasi dalam website lengkap dan jelas & 0,195 & 0,522 & Valid \\
\hline 6 & Tampilan kualitas visual dalam website menarik & 0,195 & 0,500 & Valid \\
\hline 7 & $\begin{array}{l}\text { Mengunjungi website Taman Wisata Matahari sangat } \\
\text { bermanfaat bagi saya }\end{array}$ & 0,195 & 0,612 & Valid \\
\hline 8 & $\begin{array}{l}\text { Fitur-fitur dalam website Taman Wisata Matahari sangat } \\
\text { menyenangkan }\end{array}$ & 0,195 & 0,495 & Valid \\
\hline 9 & $\begin{array}{l}\text { Mengunjungi website Taman Wisata Matahari sangat } \\
\text { membosankan }\end{array}$ & 0,195 & 0,225 & Valid \\
\hline 10 & Website Taman Wisata Matahari menarik untuk dibuka & 0,195 & 0,563 & Valid \\
\hline 11 & Mencari informasi dalam website merupakan ide yang bagus & 0,195 & 0,551 & Valid \\
\hline 12 & $\begin{array}{l}\text { Membuka website Taman Wisata Matahari sebelum } \\
\text { berkunjung sangat perlu }\end{array}$ & 0,195 & 0,498 & Valid \\
\hline 13 & Semua informasi dalam website sangat menarik untuk dibaca & 0,195 & 0,605 & Valid \\
\hline 14 & Fitur-fitur dalam website sangat menarik untuk dikunjungi & 0,195 & 0,504 & Valid \\
\hline
\end{tabular}

Sumber: Hasil Olahan Data Kuesioner Menggunakan SPSS (2017)

Berdasarkan hasil uji validitas diatas maka dapat dilihat bahwa pada variabel $\mathrm{X}$ atau Perceived Quality, seluruh butiran pernyataan yang ada di dalam kuesioner dapat dinyatakan valid. Hal tersebut dapat dilihat pada kolom $r$ tabel dan $r$ hitung, seluruh butiran pernyataan menunjukkan nilai $r$ hitung lebih besar dari $\mathrm{r}$ tabel. Maka pernyataan variabel X atau Perceived Quality dinyatakan valid dan dapat dilanjutkan ke uji statistik berikutnya yaitu uji reliabilitas.

Tabel 4.6. Uji Validitas Variabel Y (Intention to Visit)

\begin{tabular}{|c|l|c|c|c|}
\hline No & \multicolumn{1}{|c|}{ Pernyataan } & r tabel & r hitung & Validitas \\
\hline 1 & $\begin{array}{l}\text { Saya terdorong untuk berkunjung langsung karena } \\
\text { informasi yang ada pada website }\end{array}$ & 0,195 & 0,712 & Valid \\
\hline 2 & $\begin{array}{l}\text { Promosi pada website mempengaruhi saya untuk } \\
\text { berkunjung langsung }\end{array}$ & 0,195 & 0,454 & Valid \\
\hline 3 & $\begin{array}{l}\text { Saya akan menyarankan orang lain unuk mengunjungi } \\
\text { website agar mendapatkan informasi sebelum } \\
\text { berkunjung langsung }\end{array}$ & 0,195 & 0,516 & Valid \\
\hline
\end{tabular}

Sumber: Hasil Olahan Data Kuesioner Menggunakan SPSS (2017)

Berdasarkan hasil uji validitas diatas maka dapat dilihat bahwa pada variabel Y atau Intention to Visit dapat dinyatakan valid. Hal tersebut dapat dilihat pada kolom $\mathrm{r}$ tabel dan $r$ hitung, seluruh butiran pernyataan diatas menunjukkan nilai $r$ hitung lebih besar dari $r$ tabel. Maka pernyataan variabel Y valid. 
Untuk menguji reliabilitas instrumen yang akan digunakan dalam penelitian ini digunakan rumus koefisien Alpha Cronbach (Arikunto, 2010: 164) dengan taraf signifikansi sebesar 0,05 dengan nilai $\mathrm{N}$ adalah 100. Berdasarkan tabel diatas dapat dilihat bahwa nilai Alpha Cronbach menunjukkan angka 0,875 dengan $\mathrm{r}$ tabel sebesar 0,195. Pada dasarnya apabila $r$ hitung $>\mathrm{r}$ tabel maka data dinyatakan valid atau reliabel. Hal ini menunjukkan bahwa butiran-butiran pernyataan yang ada di dalam kuesioner adalah reliabel.

\section{Analisis Penilaian Responden Pada Perceived Quality Website}

Dalam konsep Technology Acceptance Model (TAM) yaitu ada perceived ease of use (Persepsi Kemudahan Penggunaan), perceived usefulness (Persepsi penggunaan), attitude toward using (Sikap Terhadap Penggunaan Teknologi), behavioral intention to use (Minat Menggunakan Teknologi), dan actual technology usage (Penggunaan Teknologi Sesungguhnya) yang harus direspon responden pada website Taman Wisata Matahari, dijelaskan pada tabel berikut :

\section{Dimensi Perceived Ease Of Use (persepsi kemudahan penggunaan)}

Tanggapan responden berdasarkan dimensi perceived ease of use pada website Taman Wisata Matahari, pada tabel berikut ini:

Tabel 4.8 Responden Berdasarkan Dimensi Perceived Ease of Use pada website Taman Wisata Matahari

\begin{tabular}{|c|c|c|c|c|c|c|c|}
\hline \multirow{2}{*}{ No } & Pernyataan : & SS & $\mathbf{S}$ & $\mathbf{R}$ & TS & STS & \multirow{2}{*}{ Total } \\
\hline & Bobot Jawaban : & 5 & 4 & 3 & 2 & 1 & \\
\hline 1 & $\begin{array}{l}\text { Desain halaman muka } \\
\text { (homepage) website menarik dan } \\
\text { mudah dimengerti }\end{array}$ & 25 & 63 & 9 & 3 & - & 100 \\
\hline & Skor & 125 & 252 & 27 & 6 & - & 410 \\
\hline \multicolumn{7}{|c|}{$\begin{array}{rr}\text { Rata-rata Skor } \\
\end{array}$} & 4,10 \\
\hline 2 & $\begin{array}{l}\text { Kemudahan dalam mencari } \\
\text { informasi (promosi tiket masuk, } \\
\text { harga spesial tiket masuk } \\
\text { rombongan, wahana permainan, } \\
\text { dan paket wisata lainnya) }\end{array}$ & 23 & 74 & 2 & - & 1 & 100 \\
\hline & Skor & 115 & 296 & 6 & - & 1 & 418 \\
\hline \multicolumn{7}{|c|}{ Rata-rata Skor } & 4,18 \\
\hline 3 & $\begin{array}{l}\text { Website mudah diakses dari } \\
\text { komputer maupun HP }\end{array}$ & 25 & 69 & 4 & 1 & 1 & 100 \\
\hline & Jumlah & 125 & 276 & 12 & 2 & 1 & 416 \\
\hline \multicolumn{7}{|c|}{ Rata-rata Skor } & 4,16 \\
\hline & Rata-rata Skor keseluruhan & $4,10+$ & $8+4$, & 12,6 & $=4,1$ & & 4,15 \\
\hline
\end{tabular}

Sumber : Hasil Olahan Kuesioner (2017)

Pernyataan pertama yaitu fitur-fitur dalam website mudah dipahami oleh pengguna, dengan perolehan nilai rata-rata 4,10 yang berarti pengguna dapat dengan mudah memahami fitur-fitur yang ada dalam website. Pernyataan kedua yaitu informasi mudah didapatkan, dengan nilai perolehan rata-rata 4,18. Menunjukan bahwa selama ini 
pengguna sangat terbantu dengan adanya informasi-informasi yang ada pada website Taman Wisata Matahari. Pernyataan ketiga yaitu website mudah diakses dengan komputer maupun telepon genggam, dengan nilai rata-rata 4,16. Berarti, pengguna merasa website Taman Wisata Matahari sangat mudah diakses menggunakan komputer maupun HP.

Dari tabel tersebut dapat disimpulkan bahwa perceived ease of use (persepsi kemudahan penggunaan) website Taman Wisata Matahari seperti fitur-fitur, kemudahan mendapatkan informasi, dan kemudahan mengakses website mendapat nilai rata-rata 4,15. Jadi perceived ease of use (persepsi kemudahan penggunaan) website Taman Wisata Matahari sudah memberi kemudahan penggunaan kepada pengguna website.

\section{Dimensi Perceived Usefulness (persepsi penggunaan)}

Berikut peneliti cantumkan hasil tanggapan responden berdasarkan Dimensi perceived usefulness pada website Taman Wisata Matahari, dapat dijelaskan pada tabel berikut ini :

Tabel 4.9 Tanggapan Terhadap Perceived Usefulness (Persepsi Pengunaan) pada website Taman Wisata Matahari

\begin{tabular}{|c|c|c|c|c|c|c|c|}
\hline \multirow{2}{*}{ No } & Pernyataan : & SS & $\mathbf{S}$ & $\mathbf{R}$ & TS & STS & \multirow{2}{*}{ Total } \\
\hline & Bobot Jawaban : & 5 & 4 & 3 & 2 & 1 & \\
\hline 1 & $\begin{array}{l}\text { Informasi dalam website selalu } \\
\text { up to date }\end{array}$ & 17 & 70 & 13 & - & - & 100 \\
\hline \multicolumn{2}{|r|}{ Skor } & 85 & 280 & 39 & - & - & 404 \\
\hline \multicolumn{7}{|c|}{ Rata-rata } & 4,04 \\
\hline 2 & $\begin{array}{l}\text { Informasi dalam website } \\
\text { lengkap dan jelas }\end{array}$ & 21 & 72 & 7 & - & - & 100 \\
\hline \multicolumn{2}{|r|}{ Skor } & 105 & 288 & 21 & - & - & 414 \\
\hline \multicolumn{7}{|c|}{ Rata-rata } & 4,14 \\
\hline 3 & $\begin{array}{l}\text { Tampilan kualitas visual dalam } \\
\text { website sangat menarik }\end{array}$ & 21 & 68 & 11 & - & - & 100 \\
\hline \multicolumn{2}{|r|}{$\begin{array}{c}\text { Skor } \\
\end{array}$} & 105 & 272 & 33 & - & - & 410 \\
\hline \multicolumn{7}{|c|}{ Rata-rata } & 4,10 \\
\hline \multicolumn{7}{|c|}{ Rata-rata $(4,04+4,14+4,10=12,28: 3=4,09)$} & 4,09 \\
\hline
\end{tabular}

Sumber : Hasil Olahan Kuesioner (2017)

Pernyataan pertama yaitu infromasi dalam website selalu up to date, dengan nilai perolehan rata-rata 4,04. Dapat diartikan bahwa informasi yang ada didalam website sangat up to date dalam memperbarui informasi. Pernyataan kedua yaitu informasi didalam website lengkap dan jelas, dengan nilai rata-rata 4,14 menunjukan bahwa informasi di dalam website sangat lengkap dan jelas. Pernyataan ketiga tampilan kualitas visual dalam website sangat menarik, dengan nilai rata-rata 4,10, dapat diartikan bahwa menurut pengguna website tampilan kualitas visual dalam website sangat menarik.

Jadi dapat disimpulkan bahwa perceived usefulness (persepsi penggunaan) website Taman Wisata Matahari seperti informasi website selalu up to date, informasi dalam website lengkap dan jelas, dan tampilan kualitas visual dalam website sangat menarik 
mendapat nilai rata-rata 4,09. Jadi perceived usefulness (persepsi penggunaan) yang dimiliki website Taman Wisata Matahari mempunyai informasi yang selalu up to date mengenai acara-acara, dan informasi yang disampaikan sangat lengkap dan jelas serta memiliki tampilan kualitas visual yang cukup menarik bagi para pengguna.

\section{Dimensi Attitude Toward Using (sikap terhadap penggunaan teknologi)}

Tabel 4.10 Tanggapan Terhadap Attitude Toward Using (sikap terhadap penggunaan teknologi) pada website Taman Wisata Matahari

\begin{tabular}{|c|c|c|c|c|c|c|c|}
\hline \multirow{2}{*}{ No } & Pernyataan : & SS & $\mathbf{S}$ & $\mathbf{R}$ & TS & STS & \multirow{2}{*}{ Total } \\
\hline & Bobot Jawaban : & 5 & 4 & 3 & 2 & 1 & \\
\hline 1 & $\begin{array}{l}\text { Mengunjungi website } \\
\text { Taman Wisata Matahari } \\
\text { sangat bermanfaat bagi } \\
\text { kunjungan saya ke Taman } \\
\text { Wisata Matahari }\end{array}$ & 25 & 69 & 5 & - & 1 & 100 \\
\hline & Skor & 125 & 276 & 15 & - & 1 & 417 \\
\hline \multicolumn{7}{|c|}{ Rata-rata } & 4,17 \\
\hline 2 & $\begin{array}{l}\text { Fitur-fitur dalam website } \\
\text { Taman Wisata Matahari } \\
\text { sangat menyenangkan }\end{array}$ & 21 & 70 & 6 & 2 & 1 & 100 \\
\hline & Jumlah & 105 & 280 & 18 & 4 & - & 408 \\
\hline \multicolumn{7}{|c|}{ Rata-rata } & 4,08 \\
\hline 3 & $\begin{array}{l}\text { Mengunjungi website } \\
\text { Taman Wisata Matahari } \\
\text { sangat membosankan }\end{array}$ & 4 & 13 & 18 & 45 & 20 & 100 \\
\hline & Jumlah & 20 & 52 & 54 & 90 & 20 & 236 \\
\hline \multicolumn{7}{|c|}{ Rata-rata } & 2,36 \\
\hline \multicolumn{7}{|c|}{ Rata -rata $(4,17+4,08+2,36=10,61: 3=3,54)$} & 3,54 \\
\hline
\end{tabular}

Sumber : Hasil Olahan Kuesioner (2017)

Pernyataan pertama yaitu mengunjungi website Taman Wisata Matahari sangat bermanfaat bagi kunjungan saya ke Taman Wisata Matahari, dengan nilai perolehan ratarata 4,17. Dapat diartikan bahwa para pengunjung sebelum berkunjung ke Taman Wisata Matahari terlebih dahulu mencari informasi lewat internet tentang Taman Wisata Matahari melalui website Taman Wisata Matahari. Pernyataan kedua yaitu fitur-fitur dalam website Taman Wisata Matahari sangat menyenangkan, dengan nilai perolehan rata-rata 4,08, hal ini menunjukan bahwa tampilan-tampilan berupa gambar dari wahana dan juga paket-paket yang ditawarkan pada website Taman Wisata Matahari sangat bagus dan sesuai dengan aslinya.Pernyataan ketiga mengunjungi website Tman Wisata Matahari sangat membosankan, dengan nilai perolehan rata-rata sangat kecil yaitu 2,36. Dapat diartikan bahwa pengunjung website Taman Wisata Matahari sangat antusias dalam memilih website Taman Wisata Matahari, dan juga sangat sedikit keluhan yang disampaikan kepada pengelola tentang tampilan website Taman Wisata Matahari.

Jadi dapat disimpulkan bahwa dimensi Attitude Toward Using (sikap terhadap penggunaan teknologi) seperti mengunjungi website Taman Wisata Matahari sangat bermanfaat bagi kunjungan saya ke Taman Wisata Matahari, fitur-fitur dalam website Taman Wisata Matahari sangat menyenangkan, dan sedikit sekali yang yang menyatakan bosan membuka website Taman Matahari, kesemuanya mendapat nilai rata 3,54. 


\section{Dimensi Behavioral Intention to Use (minat menggunakan teknologi)}

Tabel 4.11 Tanggapan Terhadap Behavioral Intention To Use (minat menggunakan teknologi) pada website Taman Wisata Matahari

\begin{tabular}{|c|c|c|c|c|c|c|c|}
\hline \multirow{2}{*}{ No } & Pernyataan : & SS & $\mathbf{S}$ & $\mathbf{R}$ & TS & STS & \multirow{2}{*}{ Total } \\
\hline & Bobot Jawaban : & 5 & 4 & 3 & 2 & 1 & \\
\hline 1 & $\begin{array}{l}\text { Website Taman Wisata Matahari } \\
\text { menarik untuk dibuka }\end{array}$ & 13 & 77 & 9 & - & 1 & 100 \\
\hline & Jumlah & 65 & 308 & 27 & - & 1 & 401 \\
\hline \multicolumn{7}{|c|}{ Rata-rata } & 4,01 \\
\hline 2 & $\begin{array}{l}\text { Mencari informasi dalam webiste } \\
\text { merupakan ide yang bagus }\end{array}$ & 26 & 68 & 6 & - & - & 100 \\
\hline & Jumlah & 130 & 272 & 18 & - & - & 420 \\
\hline \multicolumn{7}{|c|}{ Rata-rata } & 4,20 \\
\hline 3 & $\begin{array}{l}\text { Membuka webiste Taman Wisata } \\
\text { Matahari sebelum berkunjung sangat } \\
\text { perlu }\end{array}$ & 22 & 73 & 5 & - & - & 100 \\
\hline & Jumlah & 110 & 292 & 15 & - & - & 417 \\
\hline \multicolumn{7}{|c|}{ Rata-rata } & 4,17 \\
\hline \multicolumn{7}{|c|}{ Rata-rata $(4,01+4,20+4,17=12,38: 3=4,13)$} & 4,13 \\
\hline
\end{tabular}

Sumber : Hasil Olahan Kuesioner (2016)

Pada pernyataan pertama yaitu website Taman Wisata Matahari menarik untuk dibuka, dengan nilai perolehan rata-rata 4,01. Berarti pengguna sangat tertarik untuk membuka website Taman Wisata Matahari. Pernyataan kedua yaitu mencari informasi dalam website merupakan ide yang bagus, dengan nilai perolehan rata-rata 4,20. Menunjukan bahwa pengguna merasa mencari informasi dalam website Taman Wisata Matahari adalah ide yang bagus. Pernyataan ketiga yaitu membuka website Taman Wisata Matahari sebelum berkunjung sangat perlu, dengan poin 4,17. Dapat diartikan bahwa membuka website Taman Wisata Matahari sebelum melakukan kunjungan sangat perlu.

Dapat disimpulkan bahwa Behavioral Intention to use (minat menggunakan teknologi) pengguna terhadap website Taman Wisata Matahari seperti website Taman Wisata Matahari menarik untuk dibuka, mencari informasi dalam website merupakan ide yang bagus, dan membuka website Taman Wisata Matahari sebelum berkunjung sangat perlu mendapat nilai rata-rata 4,13. Jadi minat menggunakan teknologi oleh pengguna terhadap website Taman Wisata Matahari sangat menarik untuk dibuka, serta mencari informasi dalam website sebelum berkunjung merupakan ide yang sangat bagus dan sangat perlu.

\subsubsection{Actual Technology Usage (penggunaan teknologi sesungguhnya)}

Tabel 4.12 Tanggapan Terhadap Actual Technology Usage (penggunaan teknologi sesungguhnya) pada website Taman Wisata Matahari

\begin{tabular}{|c|c|c|c|c|c|c|c|}
\hline \multirow{2}{*}{ No } & Pernyataan & SS & ST & CS & TS & STS & \multirow{2}{*}{ Total } \\
\cline { 2 - 7 } & Bobot Jawaban & 5 & 4 & 3 & 2 & 1 & \multirow{2}{*}{} \\
\hline
\end{tabular}




\begin{tabular}{|c|c|c|c|c|c|c|c|}
\hline 1 & $\begin{array}{l}\text { Semua informasi dalam website } \\
\text { sangat menarik untuk dibaca }\end{array}$ & 19 & 71 & 10 & - & - & 100 \\
\hline & Jumlah & 95 & 284 & 30 & - & - & 409 \\
\hline \multicolumn{7}{|c|}{ Rata-rata } & 4,09 \\
\hline 2 & $\begin{array}{l}\text { Fitur-fitur dalam website sangat } \\
\text { menarik untuk dikunjungi }\end{array}$ & 14 & 78 & 8 & - & - & 100 \\
\hline & Jumlah & 70 & 312 & 24 & - & - & 406 \\
\hline \multicolumn{7}{|c|}{ Rata-rata } & 4,06 \\
\hline \multicolumn{7}{|c|}{ Rata-rata } & 4,08 \\
\hline
\end{tabular}

Sumber : Hasil Olahan Kuesioner (2017)

Pernyataan pertama semua informasi dalam website sangat menarik untuk dibaca, nilai rata-rata 4,09. Berarti pengguna merasa informasi dalam website sangat menarik untuk dibaca. Pernyataan kedua yaitu fitur-fitur dalam website sangat menarik untuk dikunjungi, dengan nilai rata-rata 4,06. Menunjukan bahwa fitur-fitur yang ada pada website sangat menarik untuk dikunjungi dan pengguna mengunjungi setiap fitur yang ada dalam website Taman Wisata Matahari.

Jadi dapat disimpulkan bahwa Actual Technology Usage (penggunaan teknologi sesungguhnya) pengguna terhadap website Taman Wisata Matahari seperti informasi dalam website sangat menarik untuk dikunjungi, dan fitur-fitur dalam website sangat menarik untuk dibaca mendapat nilai rata-rata 4,08. Jadi actual technology usage pengguna terhadap website Taman Wisata Matahari sangat menarik untuk dikunjungi dan dibaca, serta tidak membingungkan pengguna dalam menggunakan website Taman Wisata Matahari. Perolehan total rata-rata pada kualitas website Taman Wisata Matahari dapat dijelaskan pada tabel berikut ini :

Tabel 4.13 Total Rata-rata Pernyataan Variabel X (Perceived Quality)

\begin{tabular}{|c|c|c|}
\hline No & Pernyataan & $\begin{array}{l}\text { Nilai } \\
\text { Rata2 }\end{array}$ \\
\hline 1 & Fitur-fitur dalam website mudah dipahami & 4,10 \\
\hline 2 & Informasi mudah didapatkan (jam operasional, lokasi, jadwal pameran, dan berita) & 4,18 \\
\hline 3 & Website mudah di akses menggunakan komputer maupun telepon genggam & 4,16 \\
\hline 4 & Informasi dalam website selalu up to date & 4,04 \\
\hline 5 & Informasi di dalam website lengkap dan jelas & 4,14 \\
\hline 6 & Tampilan kualitas visual dalam website sangat menarik & 4,10 \\
\hline 7 & $\begin{array}{l}\text { Mengunjungi website Taman Wisata Matahari sangat bermanfaat bagi kunjungan } \\
\text { saya ke Taman Wisata Matahari }\end{array}$ & 4,17 \\
\hline 8 & Fitur-fitur dalam website Taman Wisata Matahari sangat menyenangkan & 4,08 \\
\hline 9 & Mengunjungi website Taman Wisata Matahari sangat membosankan & 2,36 \\
\hline 10 & Website Taman Wisata Matahari menarik untuk dibuka & 4,01 \\
\hline 11 & Mencari informasi dalam website merupakan ide yang bagus & 4,20 \\
\hline 12 & Membuka website Taman Wisata Matahari sebelum berkunjung sangat perlu & 4,17 \\
\hline 13 & Semua informasi dalam website sangat menarik untuk dibaca & 4,09 \\
\hline 14 & Fitur-fitur dalam website sangat menarik untuk dikunjungi & 4,06 \\
\hline \multicolumn{2}{|r|}{ Total Rata-Rata } & 3,99 \\
\hline
\end{tabular}

Sumber : Hasil Olahan Kuesioner (2017)

Berdasarkan tabel tersebut diperoleh total rata-rata pada perceived quality website Taman Wisata Matahari yang diukur dengan konsep TAM adalah 3,99. Dapat diartikan bahwa kualitas website Taman Wisata Matahari dinilai baik oleh pengguna untuk 
memudahkan pengguna dalam mencari informasi. Pernyataan website mudah diakses menggunakan komputer maupun telepon genggam mendapatkan nilai rata-rata tertinggi yaitu 4,18 yang berarti pengguna merasa mengaskses website Taman Wisata Matahari sangat mudah, baik menggunakan komputer maupun telepon genggam, pernyataan semua informasi dalam website sangat menarik untuk dibaca mendapatkan nilai rata-rata yaitu 4,16 yang berarti pengguna merasa informasi dalam website sangat menarik untuk dibaca oleh pengunjung website Taman Wisata Matahari, pengelola website sudah membuat tampilan informasi dalam website lebih menarik untuk dibaca.

\section{Analisis Minat Berkunjung}

Dalam analisa minat berkunjung ada beberapa indikator yang harus direspon oleh responden dalam penelitian ini. Adapun pembahasannya sebagai berikut :

Tabel 4.14 Tanggapan Terhadap Minat Berunjung ke Taman Wisata Matahari

\begin{tabular}{|c|c|c|c|c|c|c|c|}
\hline \multirow{2}{*}{ No } & Pernyataan : & SS & $\mathbf{S}$ & $\mathbf{K S}$ & TS & STS & \multirow{2}{*}{ Total } \\
\hline & Bobot Jawaban : & 5 & 4 & 3 & 2 & 1 & \\
\hline 1 & $\begin{array}{l}\text { Saya terdorong untuk berkunjung } \\
\text { langsung karena informasi yang } \\
\text { ada pada website Taman Wisata } \\
\text { Matahari }\end{array}$ & 16 & 80 & 3 & 1 & - & 100 \\
\hline & Jumlah & 80 & 320 & 9 & 2 & - & 411 \\
\hline \multicolumn{7}{|c|}{ Rata-rata } & 4,11 \\
\hline 2 & $\begin{array}{lr}\text { Promosi pada } & \text { wesbsite } \\
\text { mempengaruhi saya } & \text { untuk } \\
\text { berkunjung langsung ke } & \text { Taman } \\
\text { Wisata Matahari } & \\
\end{array}$ & 15 & 81 & 4 & - & - & 100 \\
\hline & Jumlah & 75 & 324 & 12 & - & - & 411 \\
\hline \multicolumn{7}{|c|}{ Rata-rata } & 4,11 \\
\hline 3 & $\begin{array}{l}\text { Saya akan menyarankan orang lain } \\
\text { untuk mengunjungi website agar } \\
\text { mendapatkan informasi sebelum } \\
\text { berkunjung }\end{array}$ & 22 & 74 & 4 & - & - & 100 \\
\hline & Jumlah & 110 & 296 & 12 & - & - & 418 \\
\hline \multicolumn{7}{|c|}{ Rata-rata } & 4,18 \\
\hline \multicolumn{7}{|c|}{ Rata-rata $(4,11+4,11+4,18=12,40: 3=4,13)$} & 4,13 \\
\hline
\end{tabular}

Sumber : Hasil Olahan Kuesioner (2017)

Pernyataan pertama yaitu saya terdorong untuk berkunjung langsung karena informasi yang ada pada website, dengan nilai perolehan rata-rata 4,11 . Dapat diartikan bahwa pengguna website merasa terdorong untuk berkunjung langsung ke Taman Wisata Matahari karena mendapatkan informasi pada website Taman Wisata Matahari. Pernyataan kedua yaitu promosi pada website mempengaruhi saya untuk berkunjung langsung, dengan perolehan nilai rata-rata 4,11. Dapat disimpulkan bahwa pengguna website Taman Wisata Matahari terpengaruh oleh promosi yang ada pada website Taman Wisata Matahari untuk berkunjung langsung ke Taman Wisata Matahari. Pernyataan ketiga yaitu saya akan menyarankan orang lain untuk mengunjungi website agar mendapatkan informasi sebelum berkunjung langsung, dengan perolehan nilai rata-rata 
4,18. Dapat disimpulkan bahwa pengguna website akan menyarankan orang lain yang akan berkunjung ke Taman Wisata Matahari untuk membuka website Taman Wisata Matahari agar mendapatkan informasi sebelum berkunjung langsung. Perolehan rata-rata Minat Berkunjung pengguna website dapat dijelaskan pada tabel berikut :

Tabel 4.15 Total Rata-rata Pernyataan Variabel Y

\begin{tabular}{|c|l|c|}
\hline No & \multicolumn{1}{|c|}{ Minat Berkunjung } & Nilai rata-rata \\
\hline 1 & $\begin{array}{l}\text { Saya terdorong untuk berkunjung langsung karena informasi } \\
\text { yang ada pada website }\end{array}$ & 4,11 \\
\hline 2 & $\begin{array}{l}\text { Promosi pada website mempengaruhi saya untuk berkunjung } \\
\text { langsung }\end{array}$ & 4,11 \\
\hline 3 & $\begin{array}{l}\text { saya akan menyarankan orang lain untuk mengunjungi website } \\
\text { agar mendapatkan informasi sebelum berkunjung langsung }\end{array}$ & 4,18 \\
\hline \multicolumn{2}{|c|}{ Total Rata-Rata } & $12,40 / 3=4,13$ \\
\hline
\end{tabular}

Sumber : Hasil Olahan Kuesioner (2017)

Berdasarkan tabel 4.15 diperoleh rata-rata penilaian responden pada minat berkunjung yaitu 4,13. Dapat disimpulkan bahwa responden merasa tertarik untuk berkunjung langsung ke Taman Wisata Matahari, hal ini dapat dilihat dari rata-rata minat responden yang menilai baik yaitu 4,13.

Responden menyatakan bahwa website sangat mampu mendorong pengguna website berkunjung langsung karena informasi dan promosi pada website Taman Wisata Matahari sangat menarik untuk dikunjungi oleh pengguna. Dengan nilai rata-rata minat berkunjung 4,13 dapat diartikan bahwa website Taman Wisata Matahari sangat mampu mendorong minat berkunjung pengguna untuk melakukan kunjungan maupun kunjungan ulang ke Taman Wisata Matahari.

\section{Analisis Pengaruh Perceived Quality Website Terhadap Minat Berkunjung}

Analisis Regresi Linier Sederhana digunakan dalam penelitian ini dengan tujuan untuk memprediksikan seberapa besar perubahan nilai variabel dependen (Y) bila variabel independen $(\mathrm{X})$ dinaikkan atau diturunkan. Perhitungan statistik dalam analisis regresi linier sederhana dengan menggunakan bantuan SPSS version 23 for windows. Hasil pengolahan data menggunakan program SPSS diperoleh dalam tabel berikut ini :

Tabel 4.16 Hasil Pengolahan Data Regresi Linier Sederhana Coefficients $^{\mathrm{a}}$

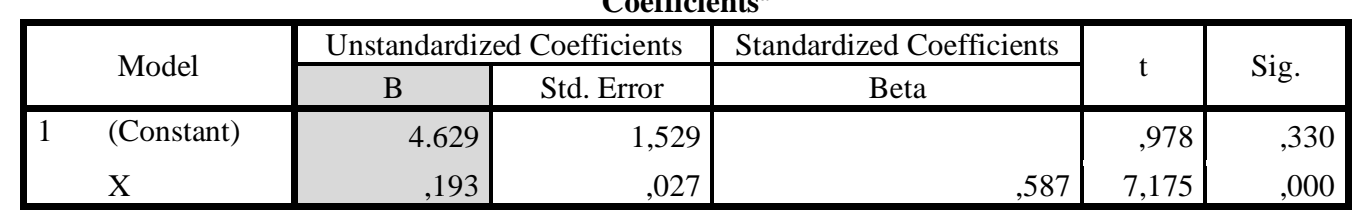

Sumber : Hasil Olahan Data Peneliti, 2017

Berdasarkan tabel 4.13 dapat dibuat model regresisebagai berikut :

$Y=a+b x=4,629+0,193 x$ 
Dari persamaan regresi tersebut terlihat bahwa pengaruh perceived quality website sebagai media promosi yang diukur menggunakan TAM terhadap minat berkunjung adalah searah (positif) yang artinya, perceived quality website sebagai media promosi akan memberikan pengaruh terhadap minat berkunjung ke Taman Wisata Matahari. Hal tersebut ditunjukan pada koefisien regresi atau nilai $\mathrm{b}$ dalam persamaan regresi tersebut yang menunjukan angka positif sebesar 0,193 . Setiap penambahan 1 nilai x maka Y akan bertambah sebesar 0,193.

\section{Uji Hipotesis}

Untuk menguji adakah pengaruh antara variabel bebas terhadap variabel terikat, maka dilakukan uji T yang ditampilkan pada tabel dibawah ini :

Tabel 4.17 Hasil Pengolahan Uji T

Coefficients $^{\mathrm{a}}$

\begin{tabular}{|c|c|c|c|c|c|c|}
\hline & \multirow{2}{*}{ Model } & \multicolumn{2}{|c|}{$\begin{array}{l}\text { Unstandardized } \\
\text { Coefficients } \\
\end{array}$} & \multirow{2}{*}{$\begin{array}{c}\begin{array}{c}\text { Standardized } \\
\text { Coefficients }\end{array} \\
\text { Beta }\end{array}$} & \multirow{2}{*}{$\mathrm{t}$} & \multirow[t]{2}{*}{ Sig. } \\
\hline & & $\mathrm{B}$ & Std. Error & & & \\
\hline \multirow[t]{2}{*}{1} & (Constant) & 4,629 & 1,529 & & ,978 & ,330 \\
\hline & $X$ & , 193 & ,027 & ,587 & 7,175 & 000 \\
\hline
\end{tabular}

Sumber : Hasil Olahan Data Peneliti, 2017

Selain menggambarkan persamaan regresi tabel diatas juga menampilkan uji signifikansi dengan uji t yaitu untuk mengetahui apakah ada pengaruh yang signifikan antara variabel $X$ terhadap variabel $Y$. Dari tabel coefficients dapat diketahui nilai t hitung 7,175 dengan nilai signifikansi $0,000<0,05$. Dengan demikian maka Ho ditolak dan H1 diterima yang berarti ada pengaruh antara variabel perceived quality website sebagai media promosi $(\mathrm{X})$ dengan minat berkunjung $(\mathrm{Y})$.

\section{Koefisien Determinasi}

Analisis koefisien determinasi $\left(\mathrm{R}^{2}\right)$ digunakan untuk mengetahui seberapa besar persentase sumbangan pengaruh variabel independen terhadap variabel dependen. Berikut ini adalah hasil olahan data mengenai koefisien determinasi yang didapat antara perceived quality website $(\mathrm{X})$ terhadap minat berkunjung $(\mathrm{Y})$ :

Tabel 4.18 Hasil Pengolahan Data Analisis Koefisien Determinasi Model Summary

\begin{tabular}{|c|c|c|c|c|}
\hline Model & $\mathrm{R}$ & $\mathrm{R}$ Square & $\begin{array}{c}\text { Adjusted } \mathrm{R} \\
\text { Square }\end{array}$ & $\begin{array}{c}\text { Std. Error of the } \\
\text { Estimate }\end{array}$ \\
\hline 1 &, $587^{\mathrm{a}}$ &, 344 &, 338 & 1,486 \\
\hline
\end{tabular}

Sumber : Hasil Olahan Data Peneliti, 2017

Tabel 4.18 menunjukkan hasil Model Summary nilai koefisien determinasi R yang menunjukkan tingkat hubungan antara variabel bebas terhadap variabel terikat yaitu 0,587 dan nilai $\mathrm{R}^{2}$ ( $\mathrm{R}$ square) menunjukan besarnya kontribusi 0,344 atau $34,4 \%$. Jika dimasukan ke dalam rumus maka : 


$$
\begin{aligned}
\mathrm{KD} & =\mathrm{R}^{2} \times 100 \%, \\
\mathrm{KD} & =0,344 \times 100 \% \\
\mathrm{KD} & =34,4 \%
\end{aligned}
$$

Berdasarkan perhitungan di atas, maka dapat diartikan bahwa secara keseluruhan pengaruh perceived quality website terhadap minat berkunjung adalah sebesar $34,4 \%$ dan sisanya sebesar $65,6 \%$ dipengaruhi oleh faktor lain yang tidak termasuk dalam penelitian ini.

\section{DAFTAR PUSTAKA}

Alma, B. (2014). Manajemen Pemasaran dan Pemasaran Jasa, Bandung, CV Alfabeta.

Ardhiani, L, N. (2015). Analisis Faktor-faktor Penerimaan Penggunaan Quipperschool.com Dengan Menggunakan Pendekatan Technology Acceptance Model dan Theory Of Planned Behavior (TPB) di SMA Negeri 7, Yogyakarta. Dicatat dari : http://eptints.uny.ac.id/20550.1/lisa\% 20noor\%20ardhiani_10520241012.pdf 18 April 2016

Hanggono, A, A \& Handayani, S, R. (2015.) Analisis Atas Praktek Technology Acceptance Model Dalam Mendukung Bisnis Online Dengan Memanfaatkan Jejaring Sosial Instagram, Kota Malang. Dicatat dari : http://administrasibisnis.studentjournel.ub.ac.id/45642/1107_purnawan.pdf18 April 2016

Hidayat, R. (2010). Cara Praktis Membangun Website Gratis. Jakarta: PT. Elex Media Komputind.

Ismayanti. (2010). Pengantar Pariwisata. Jakarta: PT.Gramedia Widiasarana Indonesia.

Kotler, P \& Kevin L, K. (2009). Manajemen Pemasaran Jilid 1 Edisi 12. Indonesia : PT. Macanan Jaya Cemerlang.

Kotler, P \& Armstrong, G. (2012). Prinsip-Prinsip Pemasaran. Jakarta: Erlangga.

Kotler, K. (2012). Marketing Management 14th Ed. Pearson Education

Pajlin,E, J. (2016), Analisis Perceived Quality Website Sebagai Media Promosi dan Pengaruh Terhadap Minat Berkunjung di Galeri Nasional Indonesia, Universitas Sahid Jakarta

Purnawan, M, R. (2015). Analisis Faktor-faktor Yang Berpengaruh Terhadap Kunjungan Wisatawan Ke Museum. Semarang. Dicatat dari : http://eprints.undip.ac.id/45642/1107_purnawan.pdf 18 April 2016

Rangkuti, F. (2009). Strategi Promosi Yang Kreatif \& Analisis Kasus Integrated Marketing Communication. Jakarta: PT.Gramedia Pustaka Utama.

Sherina. D, Ni L. N \& Suartana, I. W. (2014). Analisis Technology Acceptance Model Terhadap Penggunaan Sistem Informasi di Nusa Dua Beach Hotel \& Spa. Denpasar.

Dicatat dari

http://ojs.unud.ac.id/index.php/akuntansi/article/view/7797, 18 April 2016

Sugiyono. (2011). Metode Penelitian Bisnis. Bandung : CV. ALFABETA.

Tjiptono, F. (2014). Pemasaran Jasa. Yogyakarta : Andi. 